\title{
32 KNOWLEDGE MANAGEMENT SYSTEMS: HYPE, HOPE, OR FOLLY?
}

\author{
Bob Galliers \\ Department of Information Systems \\ London School of Economics \\ United Kingdom \\ Ellen Enkel \\ KnowledgeSource \\ University of St. Gallen \\ Switzerland \\ Lisa D. Murphy \\ Ourso College of Business Administration \\ Louisiana State University \\ U.S.A. \\ Sue Newell \\ Royal Holloway School of Management \\ University of London \\ United Kingdom
}

\begin{abstract}
This panel questions whether knowledge management $(K M)$, and more specifically knowledge management systems (KMS), offer real hope for organizations in harnessing the undoubted power and capability of information and communication technology (ICT) as we enter the new millennium. More broadly, we question whether the field of Information Systems (IS) should continue to be distracted from its natural locus of concern and competence, or claim more than it can actually achieve. As a case in point, we raise serious questions regarding ICT-enabled KM, from both theoretical and practical perspectives, utilizing research and practical experience in the U.S., UK, and German traditions. We question whether $K M$ and $K M S$ are more than the most recent in a long line of
\end{abstract}

The original version of this chapter was revised: The copyright line was incorrect. This has been corrected. The Erratum to this chapter is available at DOI: 10.1007/978-0-387-35489-7_33 


\begin{abstract}
fads and fashions embraced by the IS community that have little to offer or, conversely, whether there is real substance in them. The former line of reasoning might lead us to the conclusion that a refocusing of our attention back on the management of data is in order. This is so because IT processes data-not information and certainly not knowledge. The latter might lead us to an exciting new line of research in the field of IS and related disciplines.
\end{abstract}

\title{
1. BACKGROUND
}

In reflecting on key issues and related fundamental concepts for the new millennium, there is an understandable tendency to embrace the latest fads and fashions uncritically. This is especially so in a relatively new field such as Information Systems (IS) where advances both in information and communication technology (ICT) and its application occur rapidly and incessantly. At the very first International Conference on Information Systems, Peter Keen bemoaned the lack of a cumulative tradition in IS (Keen 1980; see also Keen 1987). Notwithstanding, this trend has continued in the two decades since. Thus, for example, prior to Keen's pronouncements-during the 1970s and early 1980s-many embraced database technology as the solution to our corporate information needs (Martin 1982). Later, during the 1980s and into the 1990s, we willingly accepted the notion that IT could lead to a sustainable competitive advantage (e.g., Porter and Millar 1985). More critical reflection (e.g., Ciborra 1994) emerged later. Similarly, business process reengineering (BPR) was proffered as the means to achieve order-of-magnitude improvements in business performance (Davenport 1993). Again, however, critical evaluation has brought the earlier claims into question (Davenport 1996; Sauer et al. 1997).

More recently, the solution to the provision of necessary information across functions, business units, and geographically dispersed organizations has been identified as ERP systems (Holland et al. 1999). A related trend in the late 1990s and into the current decade has been the emphasis on KM and KMS (e.g., Alavi and Leidner 1999; Marshall 1997). Here, the astute capture-and, more importantly, creation - of organizational knowledge is said to lead to innovation in the development of new products and services (e.g., Nonaka and Takeuchi 1995). There is even talk of wisdom management (under the guise of human resource management) these days (Turner 2000).

One can argue with some justification, therefore, that the IS field has been populated by example after example of one fad after another. There has thus been a tendency to embrace new concepts, sometimes at the expense of long 
standing issues, ${ }^{1}$ sometimes at the expense of past learning about IS design and implementation. So, for example, while Davenport (1996) refers to BPR as "the fad that forgot people," similarly KM has been criticized for emphasizing technology at the expense of people (Swan et al. 1999).

In this panel, we present contrasting perspectives on $\mathrm{KMS}$ in an attempt to lay the basis for a serious debate on the role of ICT in the management of knowledge. We will question whether such developments are more potentially regressive than progressive. We will question the extent to which these new, socalled radically transforming technologies have been considered in relative isolation from the more general business strategy and management of change issues, and whether they have tended to be considered from a single rather than a transdisciplinary perspective. The aim is to provoke debate and reflection on key issues confronting us in the field of organizational IS.

\section{REFERENCĖS}

Alavi, M., and Leidner, D. E. "Knowledge Management Systems: Issues, Challenges and Benefits," Communications of the AIS (1:7), February 1999 (available at http://cais.isworld.org/articles/1-7/article.htm).

Brancheau, J. C., Janz, B. D., and Wetherbe, J. C. "Key Issues in Information Systems Management: 1994-95. SIM Delphi Results," MIS Quarterly (20:2), 1996, pp. 225-242.

Ciborra, C. "The Grassroots of IT and Strategy," in Strategic Information Systems: A European Perspective, C. Ciborra and T. Jelassi (eds.), Chichester, UK: Wiley, 1994, pp. 3-24.

Davenport, T. H. Process Innovation: Reengineering Work through Information Technology, Boston, MA: Harvard Business School Press, 1993.

Davenport, T. H. "Why Reengineering Failed: The Fad that Forgot People," Fast Company, Premier Issue, 1996, pp. 70-74.

Holland, C. P., Light, B., and Gibson, N. "A Critical Success Factors Model for Enterprise Resource Planning," in Proceedings of the Seventh European Conference on Information Systems (Volume 1), Copenhagen, Denmark, June 23-25, 1999, pp. 273-287.

Keen, P. G. W. "MIS Research: Reference Disciplines and a Cumulative Tradition," in Proceedings of the First International Conference on Information Systems, E. R. McLean (ed.), Philadelphia, PA, December 1980, pp. 9-18.

Keen, P. G. W. "MIS Research: Current Status, Trends and Needs," in Information Systems Education: Recommendations and Implementation, R. A. Buckingham, R. A. Hirschheim, F. F. Land, and C. J. Tully (eds.), Cambridge, UK: Cambridge University Press, 1987.

Marshall, L. "Facilitating Knowledge Management and Knowledge Sharing: New Opportunities for Information Professionals," Online (21:5), 1997, pp. 92-98.

Martin, J. Strategic Data Planning Methodologies, Englewood Cliffs, NJ: Prentice-Hall, 1982. Nonaka, I., and Takeuchi, H. The Knowledge-Creating Company: How Japanese Companies Create the Dynamics of Innovation, New York: Oxford University Press, 1995.

'Compare some of the key IS management issues that have persisted over time with others that have waxed and waned. See, for example Brancheau et al. (1996); Watson et al. (1997). 
Porter, M. E., and Millar V. E. "How Information Gives You Competitive Advantage," Harvard Business Review (66:4), July-August 1985, pp. 149-160.

Sauer, C, Yetton, P. W., and Associates. Steps to the Future: Fresh Thinking on the Management of IT-Based Organizational Transformation, San Francisco: Jossey-Bass, 1997.

Swan, J., Scarbrough, H., and Preston, J. "Knowledge Management: The Next Fad to Forget People?," in Proceedings of the Seventh European Conference on Information Systems (Volume II), Copenhagen, Denmark, June 23-15, 1999, pp. 668- 678.

Turner, P. "Achieving and Maintaining the Human Advantage in Organizations: The Role of HR 1979-1997 and Beyond," NBS Professional Paper No. 1, Nottingham Business School, The Nottingham Trent University, Nottingham, UK, 2000.

Watson, R. T., Kelly, G. G., Galliers, R. D., and Brancheau, J. C. "Key Issues in Information Systems Management: An International Perspective," Journal of Management Information Systems (13:4), Spring 1997, pp. 91-115.

\section{About the Panelists}

Ellen Enkel is project leader of the KnowledgeSource research center, a cooperative endeavor of the Institute of Management and the Institute of Information Management of the University of St. Gallen. She studied biology, theology, and education science at the Universities of Bielefeld and Paderborn (Germany) between 1990 and 1998. Simultaneously, she worked in the AVA Group from 1993 to 2000, first in the EDV trainer team and later in the IT basic technologies team and was responsible for creating strategic and technical concepts in IT. She is Ph.D. student at the University of Bielefeld and, from September 1999 to December 2000, was a research assistant at the Institute for Information Management of the University of St. Gallen. She is especially involved in research into knowledge networks and their social and technical aspects and in developing a method of establishing and maintaining such networks with a focus on fostering innovations and strategic management aspects. Ellen can be reached by e-mail at ellen.enkel@unisg.ch.

Bob Galliers is Professor of Information Systems and Head of Research in the Information Systems Department at the London School of Economics. Prior to joining the LSE, he was Professor of Information Management (and Dean for the period 1994-1998) at Warwick Business School. In 1998/99 he was a Visiting Professor of Information Systems at INSEAD, France. He is currently an Honorary Professor of the European Institute for Advanced Management Studies, Brussels, and is Gemini Consulting Visiting Professor in Knowledge Management at the University of St Gallen. He was previously Foundation Professor and Head of the School of Information Systems at Curtin University, Perth, Western Australia. Professor Galliers was awarded an Honorary Doctor of Science degree from Turku School of Economics and Business Administration, Finland, in 1995. He was President of the Association for Information 
Systems (AIS) in 1999 and is Program Co-chair of ICIS 2002. He is editor-inchief of the Journal of Strategic Information Systems. His books include Information Analysis (Addison-Wesley, 1987); Towards Strategic Information Systems (Abacus Press, 1987); Information Systems Research (Blackwell Scientific, 1992; Alfred Waller 1995); Information Technology and Organizational Transformation (Wiley,1997); Strategic Information Management (ButterworthHeinemann, 1994; 1999), and Rethinking Management Information Systems (Oxford University Press, 1999). His research is transdisciplinary in nature and currently focuses on innovation and knowledge management, the management of change; information systems strategy; and intra- and extra-organizational impacts of the Internet. Bob can be reached by e-mail at r.d.galliers@lse.ac.uk.

Lisa Murphy is an assistant professor of Information Systems at Ourso College of Business Administration at Louisiana State University, Baton Rouge, Louisiana. She earned her doctorate in MIS from Indiana University's Kelley School of Business after working in the aviation industry for nearly two decades. Her IS experience includes over two dozen IS development projects as well as budgeting, project management, systems planning, architecture, and infrastructure activities. Her experience as a participant in nearly all aspects of this one industry - from operating a commuter airline, to designing airports, marketing business jets, providing operations support for aircraft manufacturing, analyzing technology needs for engineering design-build teams, and assessing environmental consequences-gives her an unusual perspective on trivial, complex, transitory, long-lived, tacit, and explicit flows of information and knowledge. Most recently she has been researching the roles of digital documents in communities of practice among aerospace engineers. Lisa can be reached by email at ldmurph@lsu.edu.

Sue Newell is Professor of Innovation and Organizational Analysis in the School of Management at Royal Holloway, University of London, UK. Previously, she was Research Director at Nottingham Business School. She is a founding member of the ikon (Innovation, Knowledge and Organizational Networking) research group, based at the University of Warwick, where she was formerly employed. Her research focuses on exploring innovation as an interactive design-decision process, where networks are crucial for the sharing and integrating of knowledge. She has written extensively on this subject in journals including Organization Studies, Organization, Human Relations, Information Systems Journal, Journal of Strategic Information Systems, and European Journal of Information Systems. A second edition of her book; The Healthy Organization, is to be published by ITP later in 2001. Sue can be reached by e-mail at susan.newell@rhul.ac.uk. 